\title{
PKM Kegiatan Outbound \& Team Building Bagi Karyawan BPR Mandiri
}

\author{
Iswandi Sukartaatmadja, Nusa Muktiadji, Marwan Effendy \\ Program Studi Manajemen, Institut Bisnis dan Informatika Kesatuan \\ Bogor, Indonesia
}

E-Mail: iswandi@ibik.ac.id

\begin{abstract}
ABSTRAK
Kegiatan Outbound \& Team Building bagi Karyawan BPR Mandiri merupakan salah satu metode pembelajaran modern yang memanfaatkan keunggulan alam. Para peserta yang mengikuti kegiatan ini tidak hanya dihadapkan pada tantangan intelegensia, tetapi juga fisik dan mental. Dan ini akan terus terlatih menjadi sebuah pengalaman yang membekali dirinya dalam menghadapi tantangan yang lebih nyata. Begitu pula dalam menghadapi persaingan dikehidupan sosial masyarakat. Program Outbound \& Team Building dirancang bagi organisasi atau perusahaan yang ingin meningkatkan atau membangun sikap kepemimpinan dan kerjasama kelompok dalam diri karyawan dalam suatu perusahaan atau anggota dalam suatu organisasi. PKM ini merupakan bentuk Kerjasama STIE Kesatuan dengan BPR Mandiri dengan melaksanakan kegiatan Team Building yang dipadu dengan konsep acara Outbound untuk mengembangkan dan memperkuat sinergi kerja karyawan BPR Mandiri. Pasca PKM, karyawan BPR Mandiri membentuk komitmen bersama untuk bekerja bersama-sama mengembangkan perusahaan untuk mencapai tujuan bersama. Beberapa rencana kerja kelompok dikembangkan bersama.
\end{abstract}

Kata Kunci: sinergi kerja, team building, karyawan

\section{PENDAHULUAN}

Motivasi adalah dorongan yang menghasilkan perilaku yang diarahkan pada tujuan. Menurut pandangan psikologi, motivasi dapat dipengaruhi oleh faktor lingkungan, peran pikiran, dan harapan. Salah satu cara yang dapat dilakukan untuk meningkatkan motivasi adalah dengan kegiatan outbound. Outbound training kerapkali diadakan oleh perusahaan sebagai bentuk refreshing para karyawannya. Mereka biasanya menyelenggarakan diakhir atau awal tahun berbarengan dengan acara tahunan perusahaan. Namun, ada juga beberapa perusahaan yang menganggap outbound training tidak terlalu penting. Mereka hanya melakukan kegiatan ramah tamah sekadarnya untuk mempererat hubungan sesama karyawan. Padahal, manfaat outbound training jauh lebih besar dari itu. Ada banyak manfaat yang bisa diambil jika perusahaan secara rutin dan berkala mengadakan outbound training bagi karyawan mereka diberbagai level.

Outbound \& Team Building merupakan salah satu metode pembelajaran modern yang memanfaatkan keunggulan alam. Para peserta yang mengikuti outbound tidak hanya dihadapkan pada tantangan intelegensia, tetapi juga fisik dan mental. Dan ini akan terus terlatih menjadi sebuah pengalaman yang membekali dirinya dalam menghadapi tantangan yang lebih nyata. Begitu pula dalam menghadapi persaingan dikehidupan sosial masyarakat. Program Outbound \& Team Building dapat dirancang bagi organisasi, perusahaan atau sekolah-sekolah yang ingin meningkatkan atau membangun sikap kepemimpinan dan kerjasama kelompok dalam diri karyawan dalam suatu perusahaan atau siswa suatu sekolah atau anggota dalam suatu organisasi.

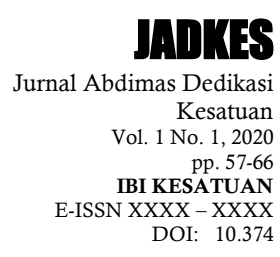

Submitted: MEI 2020

Accepted: JUNI 2020 
Kompetensi Sinergi Kerja Karyawan

\section{8}

\section{JADKES}

Jurnal Abdimas Dedikasi

Kesatuan

Vol. 1 No. 1, 2020

pp. $57-66$

IBI KESATUAN

E-ISSN XXXX - XXXX

DOI:
Bank Pekreditan Rakyat merupakan salah satu jenis bank yang dikenal melayani golongan usaha mikro, kecil dan menengah. Lokasi BPR biasanya dekat dengan tempat masyarakat yang membutuhkan sehingga BPR banyak dijumpai di setiap daerah yang tersebar di seluruh wilayah Indonesia. BPR merupakan lembaga perbankan resmi yang diatur berdasarkan pada Undang-Undang No. 7 Tahun 1992 tentang Perbankan dan sebagaimana telah disempurnakan dengan Undang-Undang No. 10 Tahun 1998. Pengertian BPR sesuai dengan UU tersebut adalah bank yang melaksanakan kegiatan usaha secara konvensional atau berdasarkan pada Prinsip Syariah yang dalam kegiatannya tidak memberikan jasa dalam lalu lintas pembayaran. Kegiatan Outbound \& Team Building diharapkan dapat menjadi bahan masukan yang berguna dalam meningkatkan atau membangun sikap kepemimpinan dan kerjasama kelompok dalam diri karyawan sehingga diharapkan akan berdampak secara positif terhadap perkembangan BPR Mandiri didalam menghadapi persaingan bisnis.

Pada tahun 1933, Dr. Kurt Hahn melarikan diri ke Inggris karena berbeda pandangan politik dengan Hitler. Dengan bantuan Lawrence Holt, seorang pengusaha kapal niaga, ia mendirikan lembaga pendidikan outbound tersebut. Hahn memakai nama Outward Bound saat mendirikan sekolahan yang terletak di Aberdovey, Wales, pada tahun 1941 Sastrohadiwiryo, (2002). Di Indonesia, metode ini diketahui baru masuk pada tahun 1990 dengan nama outward Bound Indonesia. Outbound mulai dikenal sebagai metode pelatihan untuk pengembangan diri di dalam tim. Outbound merupakan metode pelatihan untuk pengembangan diri (personal development) dan tim (team development) dalam proses mencari pengalaman melalui kegiatan di alam terbuka. Outbound tidak hanya dapat dilakukan oleh orang dewasa atau hanya di dalam dunia pekerjaan. Tetapi di Indonesia sekarang outbound sudah lebih dikembangkan lagi dengan pembelajaran untuk anak-anak yang masih belia. Diharapkan dengan outbound, maka akan tercipta komunikasi karena anak merasakan adanya kehadiran orangtua dan orangtua sendiri merasa lebih dekat secara emosional dengan sang anak. Dalam outbound, anak akan diajak mengembangkan kemampuan ESQ (emotional and spiritual quotient), disamping juga IQ (intellegent quotient). Dalam kegiatan outbound yang diikuti oleh anak, untuk sementara orangtua yang ikut outbound bersama anakpun ia harus menanggalkan peran dan statusnya untuk sementara agar lebih efektif, Sastrohadiwiryo, (2002).

Pengalaman dalam kegiatan outbound memberikan masukan yang positif dalam perkembangan kedewasaan seseorang. Pengalaman itu mulai dari pembentukan kelompok. Kemudian setiap kelompok akan menghadapi bagaimana cara bekerjasama. Bersama-sama mengambil keputusan dan keberanian untuk mengambil risiko. Setiap kelompok akan menghadapi tantangan dalam memikul tanggung jawab yang harus dilalui, Sastrohadiwiryo(2002). Tujuan utama kegiatan pelaksanaan outbound adalah melatih para peserta untuk mampu menyesuaikan diri dengan perubahan yang ada dengan membentuk sikap professionalisme para peserta yang didasarkan pada perubahan dan perkembangan karakter, komitmen serta kinerja yang diharapkan akan semakin lebih baik.

Sikap dan perilaku profesionalisme menurut Sastrohadiwiryo (2002), meliputi:

1. Terbentuknya suatu komitmen yang utuh dari setiap peserta melalui $4 \mathrm{C}$, yaitu:

a. Peningkatan kompetensi (competency),

b. Pembentukan kosepsi (conception) pemikiran yang komprehensif,

c. Terjadinya hubungan (connection) yang semakin erat diantara para bawahan dan atasan, serta

d. Munculnya keyakinan akan kepercayaan (confidence) diri akan kemampuan masing-masing pesera yang akan berpengaruh dalam membangun rasa memiliki dan bukan sekedar menjadi orang. Perubahan ini akan terlihat dari bertumbuh kembangnya rasa tanggung-jawab dalam melakukan tugas di unit kerjanya masing-masing.

2. Pola perilaku yang berkarakter dalam melakukan tugas-tugas kehidupan, 
berdisiplin, bertanggungjawab, berorientasi kemasa depan, mengutamakan tugas pengabdian, memiliki sikap, etika dan etos kerja yang tinggi.

3. Meningkatkan semangat kerja dalam menjalankan tugas dan tanggung jawab masing-masing, serta meningkatkan keberanian peserta dalam mengambil setiap resiko (risk taking) dari setiap tantangan yang dihadapi.

4. Team building yang solid yang didasarkan pada saling pengertian, kerja sama, koordinasi, menghargai perbedaan, sikap mengutamakan tugas dari pada :

5. Kepentingan pribadi. Serta meyakini bahwa keberhasilan merupakan buah dari kerjasama dan kebersamaan.

6. Peningkatan kematangan Emotional Question (EQ) melalui program Olah Rasa yang menjadi porsi perhatian outbound bahkan perhatiannya kepada pengembangan Spiritual Quotion (SQ) akan sangat membantu peserta dalam meningkatkan kematangan kemampuan menghadapi berbagai tantangan dan hambatan dalam setiap penyelesaian tugas-tugas yang dihadapi.

Adapun manfaat dari penyelenggaraan kegiatan Outbound \& Team Building bagi BPR Mandiri, yakni :

1. Untuk pengembangan diri agar peserta pelatihan menjadi pribadi yang effektif melalui pengenalan terhadap kekuatan dan kelemahan pribadi agar dapat menemukan jalan untuk memaksimalkan potensi yang dimiliki untuk berprestasi.

2. Untuk melatih peserta agar menjadi 'team player' yang handal. Dalam hal ini, peserta dilatih untuk mengoptimalkan peran dari tim dan mengatasi hambatannya yang meliputi saling ketergantungan, kerjasama, pentingnya komunikasi dan membangun suatu tim yang kompak.

3. Untuk membantu peserta menggali dan mengasah potensi kepemimpinan yang dimiliki.

\section{METODOLOGI PELATIHAN OUTBOUND}

Dalam suatu kegiatan outbound training, ada beberapa tahapan yang biasa dilakukan. Agar pelatihan outbound training bisa berjalan dengan baik dan sesuai dengan tujuan atau sasaran yang diinginkan. Setiap proses pembelajaran dalam outbound training yang efektif memerlukan tahapan berikut ini, yaitu:

a. Tahapan pembentukan pengalaman (experience)

Pada tahapan ini peserta dilibatkan alam suatu kegiatan atau permainan bersama orang lain. Kegiatan atau permainan outbound adalah salah satu bentuk pemberian pengalaman secara langsung kepada peserta pelatihan. Pengalaman langsung dalam outbound akan dijadikan wahana untuk menimbulkan pengalaman intelektual, pengalaman emosional dan pengalaman bersifat fisikal. Dengan adanya pengalaman tersebut setiap peserta siap untuk memasuki tahapan kegiatan berikutnya yang disebut dengan tahapan pencarian makna.

b. Tahapan perenungan pengalaman.

Kegiatan perenungan bertujuan untuk memproses pengalaman yang diperoleh dari kegiatan outbound yang dilakukan. Setiap peserta outbound dalam tahapan ini melakukan perenungan tentang pengalaman pribadi yang dirasakan disaat kegiatan berlangsung. Apa yang dirasakan secara intelektual, emosional dan fisikal. Dalam tahapan ini, fasilitator berusaha untuk merangsang para peserta untuk menyampaikan pengalaman pribadi masing-masing setelah terlibat di dalam kegiatan outbound tahap pertama. Dalam kegiatan perenungan outbound, peserta biasanya menceritakan pengalaman pribadinya masing-masing dalam berbagai tingkatan belajar.

c. Tahapan pembentukan konsep

Pada tahapan ini para peserta pelatihan outbound mencari makna dari pengalaman intelektual, pengalaman emosional dan pengalaman fisikal yang diperoleh dari keterlibatan dalam kegiatan outbound. Pengalaman apakah yang ditangkap dalam suatu permainan outbound, dan apa arti permainan outbound tersebut bagi

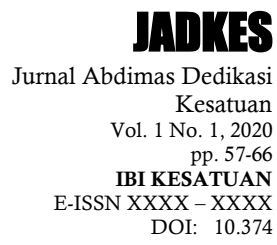


Kompetensi

Sinergi Kerja

Karyawan

60

\section{JADKES}

Jurnal Abdimas Dedikasi

Kesatuan

Vol. 1 No. 1, 2020

pp. $57-66$

IBI KESATUAN

E-ISSN XXXX - XXXX

DOI: kehidupan pribadi maupun dalam hubungan dengan orang lain. Tahapan outbound ini dilakukan sebagai kelanjutan tahap perenungan, dengan menanyakan pada peserta pelatihan outbound apa hubungan antara kegiatan yang dilakukan dengan perilaku manajemen yang sesungguhnya.

d. Pengujian konsep

Pada tahapan ini, para peserta pelatihan outbound diajak untuk merenungkan dan mendiskusikan sejauhmana konsep yang telah terbentuk di dalam tahapan tiga dapat diterapkan dalam kehidupan sehari hari, baik dalam kehidupan berkeluarga, bermasyarakat, maupun kehidupan dalam pekerjaan di kantor. Fasilitator membantu para peserta pelatihan outbound dengan cara mengajukan beberapa pertanyaan yang menggiring peserta untuk melihat relevansi dari pengalaman selama pelatihan dengan kegiatan didunia kerja sesungguhnya. Sastrohadiwiryo (2002).

\section{PELAKSANAAN KEGIATAN \\ Waktu Pelaksanaan}

Kegiatan Outbound \& Team Building bagi BPR MANDIRI diselenggarakan dengan kerjasama antara LPPM STIE Kesatuan dengan BPR Mandiri tim Outbound Kota Bogor. Acara dilakukan selama 1 hari pada tanggal 25 April 2019. Tempat penyelenggaraan di kampus STIE Kesatuan Bogor.

\section{Kerangka Pemecahan Masalah}

Permasalahan yang diangkat dalam kegiatan pengabdian pada masyarakat adalah memberikan kegiatan Outbound \& Team Building bagi karyawan BPR MANDIRI. Kerangka pemecahan masalah dimaksud dilakukan dengan menerapkan langkah kerja dalam pengabdian pada masyarakat sebagai berikut :

1. Menetapkan jumlah peserta pelatihan yakni 30 orang karyawan BPR MANDIRI di wilayah kota Bogor.

2. Seluruh peserta mengikuti pelatihan di kampus STIEK Kota Bogor yang telah dilengkapi dengan sarana dan prasarana yang memadai.

3. Materi training yang diberikan

a. Materi 1 : Memberikan training Personal Effectifeness.

b. Materi 2 : Memberikan training Effective Team

c. Materi 3 : Memberikan training Quality Leadership

Kerangka pikir untuk pemecahan masalah di atas dapat dijelaskan dalam bentuk matrik sebagai berikut :

\begin{tabular}{|c|c|}
\hline \multicolumn{1}{|c|}{ Masalah } & Upaya Pemecahan Masalah \\
\hline $\begin{array}{l}\text { Bagaimana memberikan materi training tentang } \\
\text { pengembangan diri agar peserta pelatihan } \\
\text { menjadi pribadi yang effektif. }\end{array}$ & Permainan dan game \\
\hline $\begin{array}{l}\text { Bagaimana memberikan materi training tentang } \\
\text { menjadi 'team player' yang handal. }\end{array}$ & Permainan dan game \\
\hline $\begin{array}{l}\text { Bagaimana memberikan materi training agar } \\
\text { peserta mampu menggali dan mengasah potensi } \\
\text { kepemimpinan yang dimiliki }\end{array}$ & Permainan dan game \\
\hline
\end{tabular}

\section{Khalayak Sasaran Antara Yang Strategis}

Sasaran kegiatan ini adalah karyawan BPR MANDIRI di wilayah kota Bogor. Pertimbangan penetapan sasaran kegiatan Outbound \& Team Building adalah diharapkan dapat menjadi bahan masukan yang berguna dalam meningkatkan atau membangun sikap kepemimpinan dan kerjasama kelompok dalam diri karyawan sehingga diharapkan akan berdampak secara positif terhadap perkembangan BPR Mandiri didalam menghadapi persaingan bisnis. Pertimbangan selanjutnya adalah bahwa STIE Kesatuan sebagai Perguruan Tinggi yang memiliki fungsi pengabdian kepada Masyarakat memiliki kewajiban untuk membantu BPR MANDIRI agar dapat 
mengembangkan usahanya ke arah yang lebih maju melalui motivasi dan peningkatan kemampuan SDM BPR Mandiri.

Keterikatan

Kegiatan pengabdian pada masyarakat ini diselenggarakan oleh STIE Kesatuan yang secara teknis dilakukan oleh Lembaga Penelitian dan Pengbdian kepada Masyarakat (LPPM) dengan dukungan sumber daya manusia yang memiliki latar belakang akademisi dan praktisi. Hal-hal yang berkaitan dengan sumber daya manusia serta sarana dan prasarana LPPM STIE Kesatuan dapat dijelaskan sebagai berikut :

a. Memiliki dosen yang profesional dan berpengalaman dalam menghasilkan berbagai jenis karya tulis ilmiah yang bermutu.

b. Memiliki dosen yang profesional dan berpengalaman dalam pelaksanaan kegiatan penataran dan pelatihan.

Adapun potensi yang dimiliki oleh karyawan BPR MANDIRI adalah keinginan yang kuat untuk mengetahui dan memahami manfaat kegiatan Outbound \& Team Building demi meningkatkan atau membangun sikap kepemimpinan dan kerjasama kelompok dalam diri karyawan sehingga diharapkan akan berdampak secara positif terhadap perkembangan BPR Mandiri didalam menghadapi persaingan bisnis.

\section{METODE KEGIATAN}

Metode kegiatan ini berupa kegiatan Outbound \& Team Building kepada karyawan BPR MANDIRI di wilayah kota Bogor. Setelah kegiatan dilakukan, diharapkan dapat menjadi bahan masukan yang berguna dalam meningkatkan atau membangun sikap kepemimpinan dan kerjasama kelompok dalam diri karyawan sehingga diharapkan akan berdampak secara positif terhadap perkembangan BPR Mandiri didalam menghadapi persaingan bisnis.

Berikut disajikan tahapan training yang dilakukan :

1. Tahap Persiapan

Pada tahap persiapan hal yang dilakukan meliputi :

a. Observasi calon peserta

b. Pemantapan dan penentuan lokasi dan sasaran

c. Penyusunan bahan/materi pelatihan : makalah dan modul untuk kegiatan Outbound \& Team Building bagi BPR Mandiri.

2. Tahap Pelaksanaan Kegiatan

Tahap pelaksanaan merupakan tahapan inti penyelenggaraan kegiatan Outbound \& Team Building. Pada tahap ini kegiatan yang dilakukan sebanyak 3 sesi utama, yakni :

Sesi pertama. Pada sesi ini trainer memberikan training berupa Personal Effectifeness, yaitu ditujukan untuk pengembangan diri agar peserta pelatihan menjadi pribadi yang effektif melalui pengenalan terhadap kekuatan dan kelemahan pribadi agar bisa menemukan jalan untuk memaksimalkan potensi yang dimiliki untuk berprestasi.

Sesi kedua. Pada sesi ini trainer memberikan training mengenai Effective Team Building, yaitu ditujukan untuk melatih peserta agar menjadi 'team player' yang handal. Dalam hal ini, peserta dilatih untuk mengoptimalkan peran dari tim dan mengatasi hambatannya yang meliputi saling ketergantungan, kerjasama, pentingnya komunikasi dan membangun suatu tim yang kompak.

Sesi ketiga. Pada sesi ini trainer memberikan materi training berupa Quality Leadership, yaitu untuk membantu peserta menggali dan mengasah potensi kepemimpinan yang mereka miliki. Terkait dengan hal ini, adalah bagaimana memecahkan masalah, mengambil keputusan serta melaksanakan fungsi-fungsi manajerial lainnya dalam berbagai situasi.

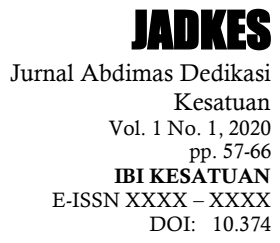

Kompetensi

Sinergi Kerja

Karyawan

\section{1}

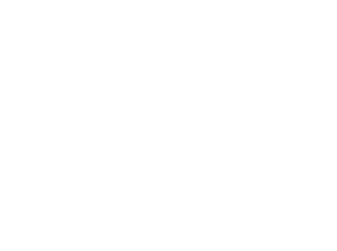


Kompetensi

Sinergi Kerja

Karyawan

62

\section{MOMKS}

Jurnal Abdimas Dedikasi Kesatuan

Vol. 1 No. 1,2020

pp. $57-66$

IBI KESATUAN

E-ISSN XXXX - XXXX

DOI:
Beberapa permainan/game yang dilakukan selama training berlangsung, sebagai berikut :

1) Permainan Menyulam/Menjahit Badan

Permainaan ini sangat unik dilakukan harus dengan kecepatan dan kerjasama secara penuh dengan kelompok.

2) Berjalan Dengan Kaki Terikat

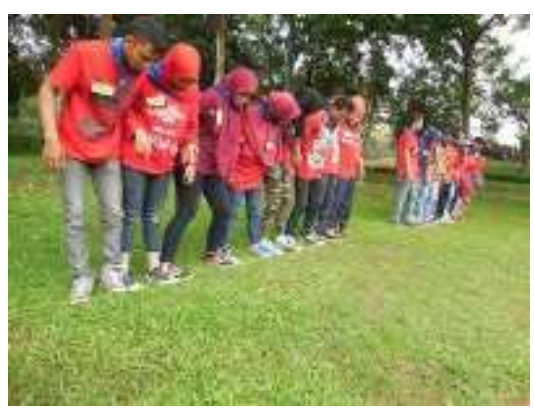

Permainan ini membutuhkan kokompakan, kebersamaan dalam kelompok, kalau tidak kalau tidak kaki akan terasa sakit, karena kaki yang terikat akan tertarik tarik oleh peserta yang lain dalam kelompok. Alat yang digunakan adalah tali kain sepanjang $\pm 50 \mathrm{~cm}$. Dengan jumlah peserta tiap kelompok sekitar $9-10$ orang.

3) Mencari Coin di dalam Tepung

Mencari Coin di dalam tepung dengan mulut, setelah didapatkan segera dikumpulkan ke team penilai, permainan ini juga sangat asyik dan unik karena sehabis mencari koin muka peserta terutama dibagian mulut banyak sekali tepung yang menempel seperti memakai bedak tetapi rasanya kasar.

4) Exalator bambu ( tangga berjalan)

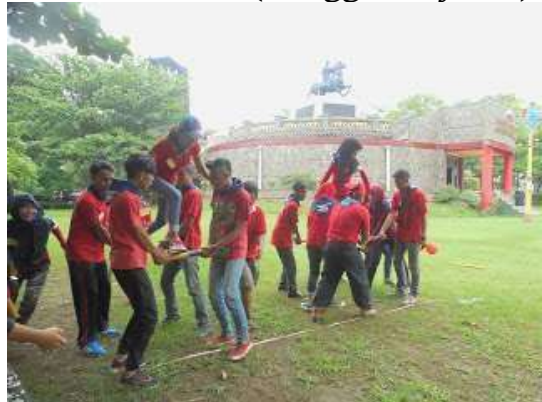

Dalam permainan ini peserta membutuhkah kekompakan, kerjasama, kekuatan, kecepatan, karena permainan ini didasari atas kerjasama dan kekompakan serta kekuakatan. Masing-masing kelompok berjumlah 9 orang, 1 orang berjalan di bambu yang panjang sekitar $50 \mathrm{~cm}$ berjumlah 4 buah 1 bambu dipegang oleh 2 orang secara estapet.

5) Benteng Takesi/Perang air

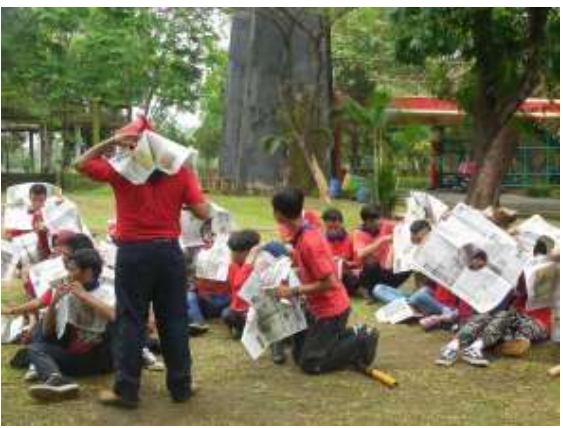

Dalam permainan ini, setiap kelompok saling bermusuhan saling lempar air yang dimasukan kedalam plastik seukuran $1 / 4 \mathrm{~kg}$, perminan ini membutuhkan keahlian, kekuatan, kerjasama, kekompakan dalam mempertahankan daerahnya masing - 
masing. Setiap kelompok saling serang untuk memperebutkan sebuat tongkat kebesaraan kelompok masing - masing, siapa yang kuat dia yang menang dalam

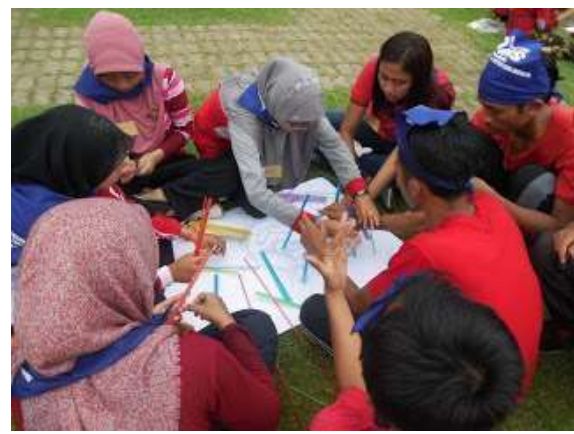

permainan ini.

6) Membangun Menara

Permainan ini membutuhkan keuletan, kesabaran, kerjasama, ketelitian, dalam membangun sebuah menara dengan bahan baku sedotan. Pembangunan menara ini membutuhkan sedotan 1 pak, isolasi, gunting. Seluruh bahan harus dirangkai sedemikian rupa sehingga membentuk sebuah menara yang kuat dari segi pondasi atau ketahanan dari terpaan angin.

7) Mengisi Air Dengan Gelas Bocor

Dalam permainan ini peserta membutuhkan keseimbangan, sejajar dan kecepatan dalam memberikan gelas bocor yang berisi air kepada peserta kelompok yang berada dibelakangnya melalui atas kepala, apabila tidak tepat dalam menyambut gelas yang bocor, maka airnya akan terbuang, mengenai kepala dan basah.

\section{HASIL DAN PEMBAHASAN \\ Hasil}

Program kegiatan pengabdian kepada masyarakat ini dilaksanakan bagi karyawan BPR MANDIRI di wilayah kota Bogor berupa kegiatan Outbound \& Team Building pada tanggal 25 April 2019. Kegiatan ini dilaksanakan dengan metode :

1. Metode Ceramah

Metode ini digunakan untuk memberikan penjelasan mengenai tata cara permainan/game yang harus dilakukan masing-masing peserta.

2. Metode Training

Metode ini digunakan agar peserta dapat melakukan kegiatan Outbound \& Team

Building sesuai dengan instruksi trainer untuk masing-masing permainan/game.

\section{Evaluasi Hasil Kegiatan}

Evaluasi proses kegiatan dilakukan dengan cara praktek serta pengamatan selama proses pelatihan diselenggarakan. Indikator keberhasilan selama proses pelatihan dilakukan, tim Lembaga Penelitian dan Pengembangan (LPPM) STIE Kesatuan melakukan penilaian terhadap keterlibatan dan kemampuan peserta pada setiap tahap training. Peserta sangat antusias dalam mengikuti acara tersebut, karena kegiatan Outbound \& Team Building dilakukan dalam suasana yang santai dengan metode-metode permainan outbound yang fun dan seru.

\section{Pembahasan}

Kegiatan program Pengabdian kepada Masyarakat yang diselenggarakan oleh Lembaga Penelitian dan Pengabdian pada Masyarakat (LPPM) STIE Kesatuan ini telah terselenggara dengan baik dan lancar. Secara umum karyawan BPR MANDIRI memberikan respon positif atas pelaksanaan kegiatan ini. Para peserta mengharapkan kegiatan ini dapat diselenggarakan secara rutin dan berkala setiap tahun dengan lokasi yang berbeda.

Dengan terselenggaranya kegiatan Outbound \& Team Building bagi BPR MANDIRI di wilayah kota Bogor diharapkan dapat menjadi bahan masukan yang berguna dalam
Kompetensi

Sinergi Kerja

Karyawan

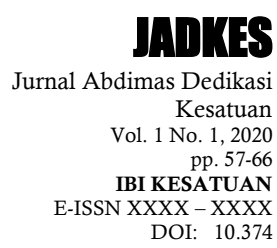


Kompetensi Sinergi Kerja Karyawan

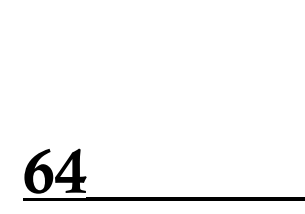

meningkatkan atau membangun sikap kepemimpinan dan kerjasama kelompok dalam diri karyawan sehingga diharapkan akan berdampak secara positif terhadap perkembangan BPR Mandiri didalam menghadapi persaingan bisnis.

Faktor-faktor lain yang diharapkan dapat terbentuk dalam kegiatan Outbound \& Team Building, sebagai berikut :

\begin{tabular}{|l|l|}
\hline Faktor Pendukung & \multicolumn{1}{|c|}{ Hasil Yang Diharapkan } \\
\hline Keakraban & $\begin{array}{l}\text { Kebersamaan dan keakraban dalam persaudaraan dan } \\
\text { persahabatan merupakan kunci utama bagi kepuasan } \\
\text { seseorang. Kebahagiaan yang dirasakan dalam kehidupan } \\
\text { berpengaruh pada kepuasan seseorang sehingga dapat } \\
\text { meningkatkan semangat belajar dan bekerja seseorang. }\end{array}$ \\
\hline $\begin{array}{l}\text { Jiwa } \\
\text { Kepemimpinan }\end{array}$ & $\begin{array}{l}\text { Kepemimpinan adalah hal yang menentukan spirit tiap orang } \\
\text { dalam beraktivitas. Karenanya peserta diajak untuk } \\
\text { menemukan basis kepemimpinan personal maupun kolektif. }\end{array}$ \\
\hline $\begin{array}{l}\text { Komunikasi } \\
\text { Empatik }\end{array}$ & $\begin{array}{l}\text { Peserta diajak untuk mengembangkan seni berkomunikasi } \\
\text { secara intra maupun interpersonal, melalui dialog, sharing } \\
\text { kelompok dimana peserta mampu saling memberi dan } \\
\text { menerima feedback dalam komunikasi yang effektif. }\end{array}$ \\
\hline $\begin{array}{l}\text { Pengambilan } \\
\text { Keputusan \& } \\
\text { Memecahkan } \\
\text { masalah }\end{array}$ & $\begin{array}{l}\text { Mengajak peserta untuk berpikir analitis dan bersikap tenang } \\
\text { dalam menghadapi masalah, berani, cermat dan } \\
\text { bertanggungjawab dalam mengambil keputusan bagi individu } \\
\text { dan kelompok. }\end{array}$ \\
\hline $\begin{array}{l}\text { Sinergi } \\
\text { Kelompok (Team } \\
\text { Work and Team } \\
\text { Building) }\end{array}$ & $\begin{array}{l}\text { Melalui pengalaman terstruktur yang sedemikian rupa, peserta } \\
\text { didorong } \\
\text { untuk mengoptimalkan pertukaran } \\
\text { peran didalam kelompok, menyadari } \\
\text { arti penting sinergi dalam menyikapi } \\
\text { keanekaragaman kelompok dan } \\
\text { mengaplikasikan dalam kehidupan sehari-hari. }\end{array}$ \\
\hline
\end{tabular}

\section{PENUTUP}

Kesimpulan

Pelaksanaan kegiatan Pengabdian kepada Masyarakat berupa kegiatan Outbound \& Team Building bagi BPR MANDIRI telah dilaksanakan dengan baik. Indikator kepuasan atas pelatihan tersebut antara lain :

1. Respon yang ditunjukkan oleh peserta selama kegiatan berlangsung. Respon tersebut berupa sangat antusiasnya peserta dalam mengikuti acara tersebut, karena kegiatan Outbound \& Team Building dilakukan dalam suasana yang santai dengan metode-metode permainan outbound yang fun dan seru.

2. Terlihatnya suasana keakraban dan sangat cair yang ditunjukkan peserta yang terdiri dari atasan dan bawahan.

3. Kegiatan pengabdian kepada masyarakat ini dapat dijadikan sharing pengetahuan hingga implementasi bagi trainer dan peserta. Sehingga menjadi sarana transfer knowledge yang dilakukan antara trainer dengan karyawan BPR Mandiri.

\section{Rekomendasi}

Rekomendasi yang dapat diberikan sehubungan dengan penyelenggaraan kegiatan kegiatan Outbound \& Team Building bagi BPR MANDIRI dapat dijelaskan sebagai berikut :

1. Peningkatan Individual Soft Skils masing masing karyawan. Kegiatan outbound bagi karyawan bermanfaat untuk melatih dan memacu agar setiap individu peserta outbound selalu mampu untuk berpikir dalam kerangka berpikir yang sistematis dan berorientasi pada hasil dan tujuan jangka panjang. 
2. Peningkatan Teamwork Skills masing-masing karyawan . Selain untuk membantu meningkatkan individual soft skills, program pelatihan outbound juga dirancang untuk menumbuhkan kesadaran tentang manfaat serta arti pentingnya kebersamaan dan bekerja secara kolektif (teamwork).

3. Sarana Refreshing Karyawan. Rutinitas kerja sehari-hari dan beban kerja yang pasti terus bertambah seiring dengan waktu tentu akan menimbulkan kejenuhan dalam diri karyawan, pada suatu waktu. Salah satu manfaat utama dari program outbound adalah juga sebagai sarana untuk break sejenak dari rutinitas kerja seharihari, melakukan kegiatan yang fun dan seru secara bersama-sama.

Kompetensi Sinergi Kerja Karyawan

\section{DAFTAR PUSTAKA}

Agustianawati, P. and Puspitasari, R., 2018. Stock Performance Analysis (Case Study PT ERATEX DJAJA, Tbk-ERTX). In THE INTERNATIONAL CONFERENCE ON ACCOUNTING AND MANAGEMENT SCIENCE (p. 107).

Andrayani, I.P. and Nurendah, Y., 2013. PROSEDUR PENJUALAN SEPEDA MOTOR PADA DEALER HONDA PT. SANPRIMA SENTOSA BOGOR (Doctoral dissertation, Institut Bisnis dan Informatika Kesatuan).

Dewi, E.T. and Srihandoko, W., 2018. Pengaruh Risiko Kredit dan Risiko Likuiditas Terhadap Profitabilitas Bank. Jurnal Ilmiah Manajemen Kesatuan, 6(3), pp.131-138.

Gitman, Lawrence J .2009. Principles of Managerial Finance, Twelfth Edition, The Addison Wesley Publishing.

Hidayat, L., Muktiadji, N. and Supriadi, Y., 2019. Pengaruh Pengetahuan Investasi Terhadap Minat Mahasiswa Berinvestasi Di Galeri Investasi Perguruan Tinggi. JASPT (Jurnal Analisis Sistem Pendidikan Tinggi Indonesia), 3(2), pp.63-70.

Iriyadi, I., Maulana, M.A. and Nurjanah, Y., 2018, December. Financial Reporting for Micro Small and Medium Enterprises Towards Industrial Revolution Era 4.0. In International Conference On Accounting And Management Science 2018 (pp. 32-38).

Koch, Timothy W, Mac Donald, S. Scot .2000. Bank Management, Fourth Edition, Orlando, The Dryden Press, Harcourt Brace College Publishers.

Lestari, A., Rosita, S.I. and Marlina, T., 2019. Analisis Penerapan Metode Full Costing Dalam Perhitungan Harga Pokok Produksi Untuk Penetapan Harga Jual. Jurnal Ilmiah Manajemen esatuan, 7(1), pp.173-178.

Manurung, T.M.S., 2017. Pengaruh motivasi dan perilaku belajar terhadap prestasi akademik mahasiswa. JAS-PT (Jurnal Analisis Sistem Pendidikan Tinggi Indonesia), 1(1), pp.17-26.

Mashadi, M., Nurachmad, E. and Mulyana, M., 2019. Analisis Deskriptif Penilaian Website Perguruan Tinggi. JAS-PT (Jurnal Analisis Sistem Pendidikan Tinggi Indonesia), 3(2), pp.97-106.

Mashadi, M., 2019. TINJAUAN PERMENPAR NO. 28-2015 USAHA PENJUALAN MAKANAN PADA SKALA MIKRO KECIL SURYA KENCANA BOGOR. IKRA-ITH EKONOMIKA, 2(3), pp.148-156.

Mulia, I., Kusuma, W.A. and Afendi, F.M., 2018. Algorithm for Predicting Compound Protein Interaction Using Tanimoto Similarity and Klekota-roth Fingerprint. Telkomnika, 16(4), pp.1785-1792.

Nurendah, Y. and Rainanto, B.H., 2019, May. The Analysis of Shoes Marketing Mix in Style Successful Benefits SMEs of Shoes Product in Bogor. In 1st International Conference on Economics, Business, Entrepreneurship, and Finance (ICEBEF 2018). Atlantis Press.

Pramiudi, U. and Setiawan, B., 2019. Penelusuran Persepsi Mahasiswa Atas Program Studi Akuntansi dan Minat Studi Lanjut. JAS-PT (Jurnal Analisis Sistem Pendidikan Tinggi Indonesia), 2(2), pp.103-113.

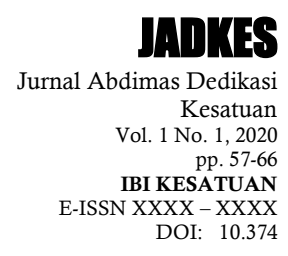


Kompetensi Sinergi Kerja Karyawan

66

\section{JADKS}

Jurnal Abdimas Dedikasi Kesatuan

Vol. 1 No. 1,2020 pp. 57-66

IBI KESATUAN

E-ISSN XXXX - XXXX

DOI:
Purba, J.H.V. and Septian, M.R., 2019. Analysis of Short Term Financial Performance: A Case Study of an Energy Service Provider. Journal of Accounting Research, Organization and Economics, 2(2), pp.113-122.

Setiawan, B., Puspitasari, R. and Manurung, T.M.S., 2016. The existence of Islamic banking in Indonesia from non-muslims perceptions. ASEAN Marketing Journal, pp.81-96.

Supriadi, Y. and Fazriani, F., 2011. Pengaruh Modal Kerja Terhadap Tingkat Likuiditas Daan Profitabilitas PT timah, Tbk dan PT Antam. Tbk. Bogor.

SYAFITRI, H.W., Nurendah, Y. and Mashadi, M., 2013. STRATEGI PELAYANAN PADA PENJUALAN SEPEDA MOTOR HONDA PADA PT. SANPRIMA SENTOSA $B O G O R$ (Doctoral dissertation, Institut Bisnis dan Informatika Kesatuan).

Triandi, T. and Fahmi, A., 2018. Pengaruh Leverage Dan Ukuran Perusahaan Terhadap Keputusan Revaluasi Aset (Studi Empiris pada Perusahaan Manufaktur yang Terdaftar di BEI Periode 2012 sd 2016). Jurnal Ilmiah Akuntansi Kesatuan, 6(2), pp.110-118. 